\title{
Optimisation of a serine protease coupling to Eudragit S-100 by experimental design techniques
}

\author{
Carla JSM Silva, ${ }^{1}$ Georg Gübitz ${ }^{2}$ and Artur Cavaco-Paulo ${ }^{1 *}$ \\ ${ }^{1}$ Department of Textile Engineering, Minho University, Guimarães, Portugal \\ ${ }^{2}$ Department of Environmental Biotechnology, Graz University of Technology, Graz, Austria
}

\begin{abstract}
A full factorial design was used to study the influence of four different variables, namely polymer concentration, carbodiimide concentration, time of reaction and blocking agent concentration, on the coupling of a serine protease into a soluble-insoluble polymer (Eudragit S-100). All of the four factors studied have played a critical role in the protease coupling. Response surface methodology was used as an optimisation strategy to attain a conjugate with high activity yield and operational stability at $60^{\circ} \mathrm{C}$. Under optimised conditions (Eudragit, $2.5 \% \mathrm{w} / \mathrm{v}$, carbodiimide, $0.2 \% \mathrm{w} / \mathrm{v}$, coupling time, $1 \mathrm{~h}$ and blocking agent concentration, $0.05 \%$ ), the conjugate activity yield was about $45 \%$ and its operational stability at $60^{\circ} \mathrm{C}$ was increased by 1.7 times. After reusing the conjugate for five cycles, the remaining activity was still $72 \%$ of the initial value when compared with the native enzyme. Several tests confirmed that the enzyme was covalently crosslinked to Eudragit, which represents an improvement in the carbodiimide coupling of proteases into soluble-insoluble polymers.

(C) 2005 Society of Chemical Industry
\end{abstract}

Keywords: serine proteases; Eudragit; coupling; factorial designs

\section{INTRODUCTION}

Enzymatic wool finishing is still rarely used as a commercial practice in the textile industry due to the undesirable side effects such as the weight loss caused by the proteolytic enzyme degradation of wool fibres. Thus, the immobilisation of proteases in soluble matrices could be a way of controlling the enzyme hydrolysis process ${ }^{1}$ and overcome the common problems of heterogeneous reaction systems, such as the poor contact between the insoluble substrate (wool) and the immobilised enzyme as well as the incomplete separation of the immobilised enzyme from unreacted solid substrates. ${ }^{2,3}$

In a previous study ${ }^{4}$ the chemical crosslinking method with glutaraldehyde was attempted in order to create soluble enzymatic conjugates, without good results, due to the few lysine residues on proteases available for crosslinking.

In recent years, stimuli-responsive or 'smart' polymers have become increasingly attractive for applications in areas ranging from medicine to biotechnology. ${ }^{5}$ These polymers are characterised by a reversible solubility by sharp modifications of experimental parameters such as temperature, $\mathrm{pH}$ or other conditions. One such polymer is Eudragit
S-100, an anionic copolymer of methacrylic acid and methyl methacrylate, which has been used for immobilisation of a variety of enzymes by covalent and non-covalent methods. ${ }^{6-8}$ It has been demonstrated that active and stable biocatalysts can be obtained by both approaches but it was also evident in all studies that adsorption to Eudragit was the prevalent method for protein coupling even in the presence of bifunctional chemical agents such as carbodiimides. ${ }^{7,8}$ It is likely that non-specific adsorption will arise as a problem to be overcome when using these polymers for conjugation with specific ligands because of their intrinsic property of reversible solubility; these polymers invariably require the presence of both hydrophilic and hydrophobic groups. The stability of the Eudragit conjugates is crucial for the purposes of bioseparation or biotransformation. Any gradual leaching of the affinity ligand or enzyme of the Eudragit during the process might be undesirable. This is especially important for processes related to the preparation of biopharmaceuticals, in which even traces of unwanted biological molecules can have deleterious effects. ${ }^{7}$

In the preliminary tests performed by our research group, the coupling of Protex Multiplus L, a

* Correspondence to: Artur Cavaco-Paulo, Department of Textile Engineering, Minho University, Guimarães, Portugal

E-mail: carjoana@det.uminho.pt

Contract/grant sponsor: FCT (Portugal); contract/grant number: PRAXIS XXI, SFRH/BD/1292/2000

Contract/grant sponsor: EU; contract/grant number: G1RD-CT-2002-00695

(Received 11 November 2004; revised version received 4 April 2005; accepted 8 April 2005)

Published online 20 July 2005 
commercial protease, to Eudragit S-100 by the carbodiimide method for the purpose of wool finishing provided a preparation with a low activity yield and low stability. Thus, the immobilisation protocol needed to be optimised for this specific enzyme, creating a conjugate more attractive for industrial application. Some studies report the coupling optimisation of several enzymes to Eudragit S-100, using, however, the one-factor-at-a-time approach. ${ }^{5,7,8}$ This approach has not led to a real understanding of the factors that can exert an interactive effect on the immobilisation of enzymes into Eudragit. Two-level factorial designs are ideal for identifying the vital few variables that significantly affect the process, and have been applied successfully to study and optimise a different number of biocatalytic ${ }^{9-11}$ and bioseparation ${ }^{12,13}$ processes.

In this study, a full factorial design was adopted for a complete understanding of the effects of polymer, concentrations of carbodiimide and blocking agent, and time of coupling in the immobilisation procedure and of their interactions. The major advantage of studying the influence of several parameters by means of factorial design methodology is to distinguish possible interactions among factors, which would not be possible by classical experimental methods, such as the one-factor-at-a-time approach. This approach is to fix all of the variables except one and then study the behaviour of the system at several levels of that variable. This method is very inefficient and takes too many experiments to come up with an answer. Therefore, factorial design requires fewer experiments, allowing the study of each variable for different conditions of the others. ${ }^{14}$

\section{MATERIALS AND METHODS \\ Enzyme and reagents}

The enzyme used in this study was the alkaline serine protease Protex Multiplus L, a modified subtilisin (EC 3.4.21.62) kindly supplied by Genencor (Leiden, Netherlands). Eudragit S-100 (MW 135000 composed of a 1:2 copolymer of methacrylic acid and methyl methacrylate) is a commercial product from Rhöm Pharma (Darmstadt, Germany). Carbodiimide hydrochloride (EDC) and ethanolamine were purchased from Sigma (St Louis, USA). All other chemicals used were of analytical grade.

\section{Immobilisation method}

The protease was covalently linked to Eudragit S100 by the carbodiimide coupling following a protocol based on the method of Arasaratnam et al. ${ }^{8}$ A solution $(\%$ in $\mathrm{w} / \mathrm{v})$ of Eudragit S-100 in phosphate buffer $(\mathrm{pH}$ 7.2 ) with $0.28 \mathrm{~mol} \mathrm{~L}^{-1}$ of $\mathrm{NaCl}$ was used. Its $\mathrm{pH}$ was raised to 11 by the addition of an $\mathrm{NaOH}$ solution and then reduced to $\mathrm{pH} 7.2$ with an $\mathrm{HCl}$ solution. To the polymer, a carbodiimide solution ( $\%$ in $w / v)$ was added while mixing for $10 \mathrm{~min}$. Then a volume of $1 \%$ (in $\mathrm{v} / \mathrm{v}$ ) of the enzyme was added. This solution was kept under stirring for $1-5 \mathrm{~h}$ at room temperature and then was mixed with a blocking solution (ethanolamine $\left.0.45 \mathrm{~g} \mathrm{~mL}^{-1}\right)(\%$ in $\mathrm{v} / \mathrm{v})$ for $1 \mathrm{~h}$ at room temperature. The $\mathrm{pH}$ of the mixture was reduced to 4.5 with acetic acid. Precipitated Eudragit-enzyme was separated by centrifugation $(13000 \times g, 10 \mathrm{~min})$ and washed alternately with $0.01 \mathrm{~mol} \mathrm{~L}^{-1}$ acetate buffer containing $0.14 \mathrm{~mol} \mathrm{~L}^{-1} \mathrm{NaCl}(\mathrm{pH} 4.5), 0.02 \mathrm{~mol} \mathrm{~L}^{-1}$ phosphate buffer containing $0.14 \mathrm{~mol} \mathrm{~L}^{-1} \mathrm{NaCl}(\mathrm{pH} 7.2$ ) and washed twice with $0.15 \mathrm{~mol} \mathrm{~L}^{-1}$ Tris $-3 \mathrm{gL}^{-1}$ Triton $\mathrm{X}-100$ buffer containing $0.015 \mathrm{~mol} \mathrm{~L}^{-1} \mathrm{CaCl}_{2}(\mathrm{pH}$ 7.6). Washing was carried out by precipitation at $\mathrm{pH}$ 4.5, resuspending in the respective buffers, mixing for $10 \mathrm{~min}$, and reprecipitation. Finally, the Eudragit-enzyme precipitate was redissolved in $100 \mathrm{~mL}$ of $0.3 \mathrm{~mol} \mathrm{~L}^{-1}$ Tris buffer containing $0.03 \mathrm{~mol} \mathrm{~L}^{-1} \mathrm{CaCl}_{2}$ (pH 7.6).

\section{Experimental design}

Four variables, which were expected to have an effect on the protease coupling to Eudragit, were identified by a preliminary search of the literature. The range and the levels of the variables investigated in this study are given in Table 1 and were chosen to encompass the range in the literature. The variables considered for the design were: Eudragit concentration $(A)$, carbodiimide concentration $(B)$, contact time $(C)$ and ethanolamine concentration $(D)$ and their influence was evaluated according to a $2^{4}$ full factorial design with four repetitions at the central point (Table 2). For statistical calculations, the variables were coded according to Eqn (1):

$$
x i=\frac{X i-X 0}{\Delta X i}
$$

where $x i$ is the independent variable coded value, $X i$ the independent variable real value, $X 0$ the independent variable real value on the centre point and $\Delta X i$ is the step change value. The runs were conducted randomly.

The 'Design-expert' version 5.0 (Stat-Ease Inc., Minneapolis, USA) was used for regression and graphical analyses of the data obtained. The conjugate activity (CA), the operational stability at $60^{\circ} \mathrm{C}$ (OS) and the remaining activity after five cycles of repeated use of the enzymes $\left(R_{5}\right)$ where taken as the responses of the design experiments. The statistical significance of the regression coefficients was determined by Student's $t$-test and that of the model equation was determined by Fischer's test. The proportion of

Table 1. Factor levels used according to the $2^{4}$ factorial design

\begin{tabular}{llll}
\hline & \multicolumn{3}{c}{ Level } \\
\cline { 2 - 4 } Variable & -1 & 0 & +1 \\
\hline A: Eudragit (\% w/v) & 0.5 & 1.5 & 2.5 \\
B: Carbodiimide (\% w/v) & 0.2 & 0.6 & 1.0 \\
C: Time (h) & 1 & 3 & 5 \\
$D:$ Blocking agent (\%) & 0.050 & 0.325 & 0.600 \\
\hline
\end{tabular}


Table 2. Values for conjugate activity (CA), operational stability at $60^{\circ} \mathrm{C}(\mathrm{OS})$ and reusability $\left(\mathrm{R}_{5}\right)$, according to the $2^{4}$ factorial design

\begin{tabular}{|c|c|c|c|c|c|c|c|}
\hline \multirow[b]{2}{*}{ Assay } & \multicolumn{4}{|c|}{ Variable } & \multicolumn{3}{|c|}{ Response } \\
\hline & $A$ & $B$ & C & $D$ & $\mathrm{CA}\left(\mathrm{UmL}^{-1}\right)$ & OS (\%) & $\mathrm{R}_{5}(\%)$ \\
\hline 1 & -1 & -1 & -1 & -1 & 3.69 & 51.2 & 13.7 \\
\hline 2 & +1 & -1 & -1 & -1 & 4.70 & 49.8 & 72.0 \\
\hline 3 & -1 & +1 & -1 & -1 & 1.08 & 58.3 & 36.8 \\
\hline 4 & +1 & +1 & -1 & -1 & 2.60 & 55.0 & 67.5 \\
\hline 5 & -1 & -1 & +1 & -1 & 3.28 & 56.0 & 22.8 \\
\hline 6 & +1 & -1 & +1 & -1 & 4.33 & 51.7 & 76.0 \\
\hline 7 & -1 & +1 & +1 & -1 & 0.77 & 37.2 & 44.3 \\
\hline 8 & +1 & +1 & +1 & -1 & 1.61 & 82.5 & 63.4 \\
\hline 9 & -1 & -1 & -1 & +1 & 2.92 & 60.6 & 16.5 \\
\hline 10 & +1 & -1 & -1 & +1 & 4.22 & 58.6 & 78.0 \\
\hline 11 & -1 & +1 & -1 & +1 & 0.46 & 75.3 & 60.2 \\
\hline 12 & +1 & +1 & -1 & +1 & 1.25 & 137.5 & 75.7 \\
\hline 13 & -1 & -1 & +1 & +1 & 2.67 & 50.0 & 19.3 \\
\hline 14 & +1 & -1 & +1 & +1 & 3.93 & 56.2 & 75.5 \\
\hline 15 & -1 & +1 & +1 & +1 & 0.46 & 83.3 & 55.6 \\
\hline 16 & +1 & +1 & +1 & +1 & 1.19 & 105.6 & 85.0 \\
\hline 17 & 0 & 0 & 0 & 0 & 1.92 & 74.3 & 55.0 \\
\hline 18 & 0 & 0 & 0 & 0 & 1.97 & 77.4 & 49.6 \\
\hline 19 & 0 & 0 & 0 & 0 & 2.04 & 59.8 & 44.2 \\
\hline 20 & 0 & 0 & 0 & 0 & 2.17 & 62.5 & 44.0 \\
\hline
\end{tabular}

variance explained by the model obtained was given by the multiple coefficient of determination, $R^{2}$. The optimum conditions were obtained by the graphical analysis using the 'Design-expert' program.

\section{Enzyme assay and protein concentration}

The activity of proteases was measured according to Silva et $a l^{4}$ using casein as substrate. One unit of activity is defined as the amount of enzyme that hydrolyses casein to produce equivalent colour to $1 \mu \mathrm{mol}$ of tyrosine, per minute, at $\mathrm{pH} 7.5$ and $37^{\circ} \mathrm{C}$ (colour measured by the Folin Ciocalteu reagent).

The total protein concentration was determined by a modification of the micro Lowry method ${ }^{15}$ using bovine serum albumin as standard and using Sigma test kit no P 5656.

\section{Gel electrophoresis}

To separate the proteins and to determine their molecular weights, SDS-PAGE was carried out using the Hoefer miniVe system from Amersham Pharmacia Biotech. The resolving gels (10\% acrylamide of about $1.5 \mathrm{~mm}$ thickness) were prepared according to the method originally described by Laemmli ${ }^{16}$ and run at a constant voltage $(120 \mathrm{~V})$. The current was stopped when the Bromophenol Blue dye marker had reached about $1 \mathrm{~cm}$ from the bottom of the gel. Following electrophoresis, to observe the protein-banding pattern on the gel, silver staining was carried out. Phosphorylase $b$ (97 kDa), albumin (66 kDa), ovalbumin (45 kDa), carbonic anhydrase $(30 \mathrm{kDa})$, trypsin inhibitor $(20.1 \mathrm{kDa})$ and $\alpha$-lactalbumin $(14.4 \mathrm{kDa})$ were used for calibration.

\section{Operational stability at $60^{\circ} \mathrm{C}$}

The native and immobilised enzymes were placed in a water bath at $60^{\circ} \mathrm{C}$ and stirred at $100 \mathrm{rpm}$, and the remaining activity was measured after $5 \mathrm{~h}$ of incubation at this temperature.

\section{Reusability}

The initial activity of the immobilised enzymes was measured. They were then subjected to five cycles of precipitation/dissolution and the activity was measured again. The cycles consisted of precipitating the polymer by lowering the $\mathrm{pH}$ to 4.5 , centrifugation, alternate washing of the precipitated polymer with acetate buffer ( $\mathrm{pH} 4.5)$ and phosphate buffer $(\mathrm{pH}$ 7.2) and redissolution in Tris $-\mathrm{Cl}$ buffer, $\mathrm{pH}$ 7.6. The activity was measured after the first, third and fifth cycles.

\section{RESULTS AND DISCUSSION}

A commercial protease was coupled to Eudragit S100 after incubation of the polymer solution with a carbodiimide (EDC) for carboxyl group activation. The enzyme concentration was kept constant during the study and the amount of polymer added was varied. The carbodiimide and blocking agent concentrations and the coupling time were also varied. The activity of the final polymer conjugate containing the immobilised protease was measured at $\mathrm{pH}$ 7.6. At this $\mathrm{pH}$, Eudragit $\mathrm{S}-100$ is in a soluble form. Table 2 shows the designed experimental matrix and its results.

After the immobilisation procedure according to the variations of the factors imposed by the design, the immobilised samples of Protex Multiplus L were analysed using gel electrophoresis, to verify the formation of macromolecular aggregates and to determine if there were major differences in their molecular weights. Figure 1 shows the results of the SDS-PAGE performed. In this technique, an anionic detergent is used (sodium dodecylsulfate-SDS) to disrupt secondary and tertiary structures of protein molecules and weak interactions among them, thus retaining only the primary amino acid structure of the protein. It is possible to see that in some of the assays the bands of native enzyme are clearly marked (A1, A3, A8, A13-A16) while in others these bands are faded (A4-A7, A9-A11) or not present (A2, A12), indicating less native enzyme or no native enzyme at all in the conjugate. These differences in the protein-banding pattern cannot be attributed to the concentration of protein in the immobilised enzymes since high protein yields, measured as the ratio between conjugate and initial protein amount (data not shown), were attained. Assay 2 had, for instance, a protein yield of $73 \%$ and lacked the band of native enzyme. Since the SDS-PAGE was performed on the immobilised samples after being subjected to an extensive washing step using high salt concentrations and surfactant, the merely-adsorbed protein was washed out and thus it may be concluded 

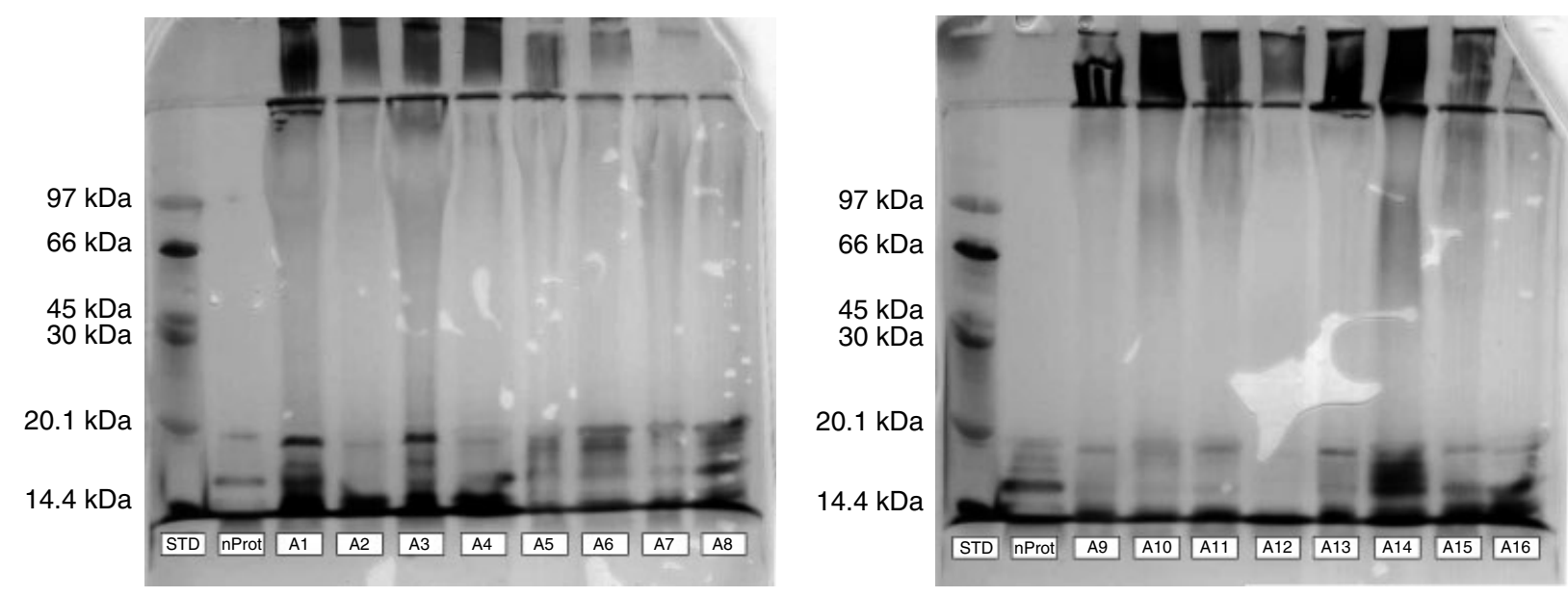

Figure 1. SDS-PAGE electrophoresis of the immobilised enzymes according to the statistical design. Lanes: STD - molecular mass markers, $n$ Prot - native Protex Multiplus L, A1 to A16 - assays nos1 to 16, in the statistical standard order (see Table 2).

Table 3. Estimated coefficients, standard errors and Student's $t$-test for conjugate activity (CA), operational stability at $60^{\circ} \mathrm{C}(\mathrm{OS})$ and reusability $\left(R_{5}\right)$, using the $2^{4}$ full factorial design

\begin{tabular}{|c|c|c|c|c|c|c|c|c|c|}
\hline \multirow[b]{2}{*}{ Factor } & \multicolumn{3}{|c|}{$\mathrm{CA}\left(\mathrm{UmL}^{-1}\right)$} & \multicolumn{3}{|c|}{ OS (\%) } & \multicolumn{3}{|c|}{$\mathrm{R}_{5}(\%)$} \\
\hline & Coefficient & Standard error & $t$ value & Coefficient & Standard error & $t$ value & Coefficient & Standard error & $t$ value \\
\hline Intercept & 2.45 & \pm 0.048 & - & 66.80 & \pm 3.18 & - & 53.89 & \pm 1.23 & - \\
\hline A: Eudragit & 0.53 & \pm 0.048 & $11.10^{\mathrm{a}}$ & 7.81 & \pm 3.18 & $2.46^{d}$ & 20.24 & \pm 1.23 & $16.47^{\mathrm{a}}$ \\
\hline B: Carbodiimide & -1.27 & \pm 0.048 & $-26.54^{a}$ & 12.54 & \pm 3.18 & $3.94^{\mathrm{C}}$ & 7.17 & \pm 1.23 & $5.83^{b}$ \\
\hline C: Time & -0.17 & \pm 0.048 & $-3.50^{c}$ & -1.49 & \pm 3.18 & -0.47 & 1.34 & \pm 1.23 & 1.09 \\
\hline$D$ : Blocking agent & -0.31 & \pm 0.048 & $-6.48^{b}$ & 11.59 & \pm 3.18 & $3.65^{c}$ & 4.33 & \pm 1.23 & $3.52^{\mathrm{c}}$ \\
\hline$A B$ & -0.046 & \pm 0.048 & -0.97 & 8.00 & \pm 3.18 & $2.52^{d}$ & -8.41 & \pm 1.23 & $-6.84^{\mathrm{b}}$ \\
\hline $\mathrm{AC}$ & -0.046 & \pm 0.048 & -0.97 & 0.87 & \pm 3.18 & 0.28 & -0.51 & \pm 1.23 & -0.41 \\
\hline$A D$ & -0.021 & \pm 0.048 & -0.44 & 3.27 & \pm 3.18 & 1.03 & 0.081 & \pm 1.23 & 0.066 \\
\hline$B C$ & -0.0025 & \pm 0.048 & -0.052 & -0.70 & \pm 3.18 & -0.22 & -0.33 & \pm 1.23 & -0.27 \\
\hline$B D$ & -0.027 & \pm 0.048 & -0.57 & 9.50 & \pm 3.18 & $2.99^{d}$ & 3.73 & \pm 1.23 & $3.04^{d}$ \\
\hline$C D$ & 0.093 & \pm 0.048 & 1.93 & -3.13 & \pm 3.18 & -0.98 & -0.72 & \pm 1.23 & -0.58 \\
\hline Centre point & -0.42 & \pm 0.11 & $-3.95^{c}$ & 1.70 & \pm 7.11 & 0.24 & -5.69 & \pm 2.75 & 2.75 \\
\hline
\end{tabular}

${ }^{\mathrm{a}} P<0.0001^{\mathrm{b}}(0.0001<P<0.001)^{\mathrm{c}}(0.001<P<0.01)^{\mathrm{d}}(0.01<P<0.05)$.

that the enzyme was in this case covalently crosslinked to the polymer. Several authors have reported that different salts and surfactants remove protein noncovalently bound to Eudragit polymers. ${ }^{7,8}$ In assays 1 and 3 there is still native enzyme in the conjugate which was desorbed by the SDS-PAGE procedure, given that the intermolecular forces that bind the protein to the polymer are very weak. ${ }^{17}$

In all the immobilised samples it is possible to observe the presence of high complexes that are trapped at the interface of the stacking gel and the running gel. These high complexes might correspond to the enzyme covalently crosslinked to the polymer that could not enter the $10 \%$ acrylamide gel, being trapped at the interface. Figure 1 also shows that all immobilised samples had different banding patterns, suggesting that all the factors considered were significant to the study.

The statistical analyses for each of the response variables evaluated, namely conjugate activity (CA), operational stability at $60^{\circ} \mathrm{C}(\mathrm{OS})$, and reusability $\left(\mathrm{R}_{5}\right)$, are summarised in Table 3 . All the four factors studied seem to have played a critical role in the protease immobilisation. Table 2 shows that the maximum values attained for conjugate activity (above $3.9 \mathrm{U} \mathrm{mL}^{-1}$ ) are found on assays $2,6,10$ and 14 . These assays also have high values for the operational stability at $60^{\circ} \mathrm{C}$ (above $50 \%$ ) and reusability (above $72 \%)$. These four assays have in common the upper level for Eudragit concentration and the lower level for carbodiimide concentration, indicating a tendency in these factors for the maximisation of these three responses. The Student's $t$-test in Table 3 confirms the higher significance of these two factors on the responses $\mathrm{CA}$ and $\mathrm{R}_{5}$, compared with the other two factors studied.

According to the Student's $t$-test results, the concentration of Eudragit, carbodiimide and blocking agent presented a significant effect (more than 95\% confidence level) for all responses tested. The other factor studied, 'time' (factor C), showed no significance at less than $95 \%$ confidence level for the responses stability and reusability and it was the less significant effect to the response 'activity'. 


\section{Effect of parameters in conjugate activity}

Analysing the response CA (remaining activity of the prepared immobilised conjugates), it was seen that all the four main factors had statistical significance at less than $99.5 \%$ of confidence level. Nevertheless, the effect of time on conjugate activity $(P=0.0037)$ is considerably lower than the other effects $(P<$ 0.0001). The Eudragit concentration has a positive effect, meaning that its increase maximises the overall response, while the other three effects have a negative effect, meaning that they should be decreased in order to maximise the retained activity of the conjugate. No interaction effects were significant at less than $95 \%$ confidence level, so the linear mathematical model proposed for this response, in actual terms, is:

$$
\begin{aligned}
\mathrm{CA}\left(\mathrm{UmL}^{-1}\right)= & 4.17+0.53 A-3.17 B \\
& -0.084 C-1.13 D
\end{aligned}
$$

This model presents an $R^{2}$ of 0.98 with an adjusted $R^{2}$ of 0.98 in good agreement with the predicted $R^{2}$ $(0.97)$ and it was significant at a confidence level less than $99.99 \%(P<0.0001)$.

Although this model presented curvature significant at less than $99.85 \%(P<0.0015)$, showing that the area studied should be extended to perform a correct analysis, our goal was to study the influence of these parameters on the three responses (activity, stability and reusability) and to maximise them in this range, so the model was accepted, and the analysis of variance (ANOVA) is shown in Table 4. Another proof of our model, as can be seen from the ANOVA table, is that it presents no lack of fit and its significance $(P<0.0001)$ is much higher than the curvature's probability level $(P=0.0015)$, having also the residuals distributed along a well randomised straight line.

In all the assays performed, the activity yield expressed by the conjugate was below $45 \%$ (achieved for assay 2), even though most of the protein added was coupled (no protein or enzyme activity were detected in the washings). These results are in agreement with the results previously published by other authors. ${ }^{2,8}$ The reduction in the activity expressed could be due to either enzyme denaturation by the coupling conditions or to the intermolecular binding between the enzyme molecules and Eudragit S-100, causing steric hindrance effects. Since the

Table 4. Analysis of variance (ANOVA) for the representative model of conjugate activity, in the area studied

\begin{tabular}{lrrrrr}
\hline Source & SS & d.f. & MS & $F$-value & $P$ \\
\hline Model & 32.31 & 4 & 8.08 & 218.35 & $<0.0001$ \\
Curvature & 0.57 & 1 & 0.57 & 15.44 & 0.0015 \\
Residual & 0.52 & 14 & 0.037 & & \\
$\quad$ Lack of Fit & 0.48 & 11 & 0.044 & 3.73 & 0.1530 \\
$\quad$ Pure error & 0.035 & 3 & 0.012 & & \\
Total & 33.40 & 19 & & & \\
\hline
\end{tabular}

$R^{2}=0.98 ; \mathrm{CV}=8.14 \%$.

$\mathrm{SS}=$ sum of squares; d.f. $=$ degrees of freedom; $\mathrm{MS}=$ mean square. activity was detected using a high molecular weight substrate (casein), the steric effects are more obvious, explaining the low conjugate activities. Arasaratnam et $a l^{8}$ showed that the covalent coupling of trypsin to Eudragit S-100 resulted in pronounced steric hindrance when acting toward the high-molecular weight substrate, even when the enzyme molecules remained catalytically active. However, for low molecular weight substrates this effect was not evident.

The contour plot for the activity in the area studied (Fig 2) confirms the linearity of the model and clearly shows that is possible to increase the final conjugate activity by decreasing carbodiimide and increasing Eudragit concentration.

The molar ratios of Protex Multiplus L coupled to Eudragit ranged from 0.36 to 1.80 (enzyme:polymer). The lower molar ratio was attained for the maximum concentration of Eudragit (corresponding to $62 \mathrm{mg}$ Protex per g Eudragit) while the molar ratio of 1.80 was attained for the lower level of Eudragit (corresponding to $308 \mathrm{mg}$ Protex per g Eudragit) since the enzyme was added in a fixed amount. To these high molar ratios, crowding of the molecules on the polymer might have happened, this can partially explain the higher activities of the conjugate when the amount of Eudragit was at its maximum, since the enzyme:polymer ratio was smaller, meaning a higher number of multivalent interactions with polymer backbone per molecule of enzyme. ${ }^{5}$ Dourado et $a l^{17}$ found that the clustering effect between Eudragit and cellulase existed when the molar ratio (enzyme:polymer) went beyond 1 .

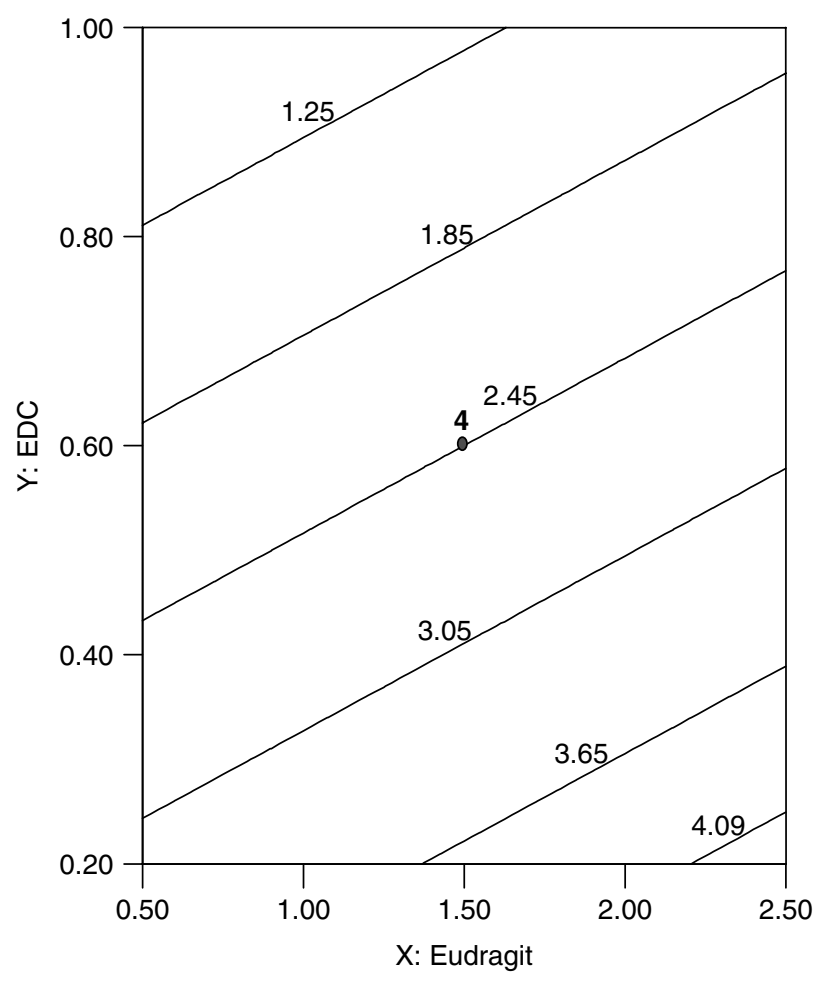

Figure 2. Contour plot showing the effect of Eudragit and carbodiimide concentration on the final activity of the conjugate. The other factors were kept at the central level. 


\section{Effect of parameters in conjugate stability}

For the operational stability, measured after keeping the immobilised enzymes for $5 \mathrm{~h}$ at $60^{\circ} \mathrm{C}$, it was seen that the factor $A$ and the interaction $A B$ showed statistical significance at a confidence level of $95 \%$ and the factors $B, D$ and the interaction $B D$ at a confidence level of $99 \%$. These factors were then included in the representative linear model, in actual terms, for this response:

$$
\begin{aligned}
\mathrm{OS}(\%)= & 57.42-4.19 A-26.72 B-9.68 D \\
& +20.00 A B+86.36 B D
\end{aligned}
$$

The statistical significance of the first-order model equation was evaluated by the $F$-test (ANOVA), which revealed that this regression is statistically significant $(P=0.0001)$ at a confidence level of $99.99 \%$ (Table 5). In addition, the model did not show lack of fit and had a correlation coefficient $\left(R^{2}\right)$ that explains $83 \%$ of the variability in the response.

Analysing the contour plot obtained for this response (Fig 3), it is possible to see, by the linear horizontal shape of the curve, that when the parameter carbodiimide concentration is in the lower level there is no interaction effect among Eudragit and carbodiimide. But when this parameter is in the upper level, the interaction effect among them becomes significant, and the higher values for the activity after $5 \mathrm{~h}$ at $60^{\circ} \mathrm{C}$ are attained using the upper level of these two factors.

The operational stability of the native enzyme after $5 \mathrm{~h}$ at $60^{\circ} \mathrm{C}$ was only $30 \%$. Thus, the conjugate is much more stable at this high temperature. This stabilising effect caused by the immobilisation into Eudragit polymers has been reported by several authors. ${ }^{2,18,19}$ Enhanced stability seems to depend on the rigid conformation of the enzyme modified by water-soluble carbodiimide and/or by covalent binding to the polymer. ${ }^{2}$ It is important to note that in the case of proteases, immobilisation is known to reduce autolysis. So, a useful outcome of immobilisation is thus enhanced storage stability of the enzyme. ${ }^{19}$

\section{Effect of parameters in conjugate reusability}

The response reusability $\left(R_{5}\right)$, which measures the activity of the immobilised preparation after five cycles

Table 5. Analysis of variance (ANOVA) to the representative model of operational stability at $60^{\circ} \mathrm{C}$, in the area studied

\begin{tabular}{lrrrcc}
\hline Source & \multicolumn{1}{c}{ SS } & d.f. & \multicolumn{1}{c}{ MS } & $F$-value & $P$ \\
\hline Model & 8107.91 & 5 & 1621.58 & 12.57 & 0.0001 \\
Curvature & 9.25 & 1 & 9.25 & 0.072 & 0.7931 \\
Residual & 1676.49 & 13 & 128.96 & & \\
$\quad$ Lack of Fit & 1451.95 & 10 & 145.20 & 1.94 & 0.3191 \\
$\quad$ Pure error & 224.54 & 3 & 74.85 & & \\
Total & 9793.65 & 19 & & & \\
\hline
\end{tabular}

$R^{2}=0.83 ; \mathrm{CV}=16.91 \%$.

$\mathrm{SS}=$ sum of squares; d.f. = degrees of freedom; MS = mean square.

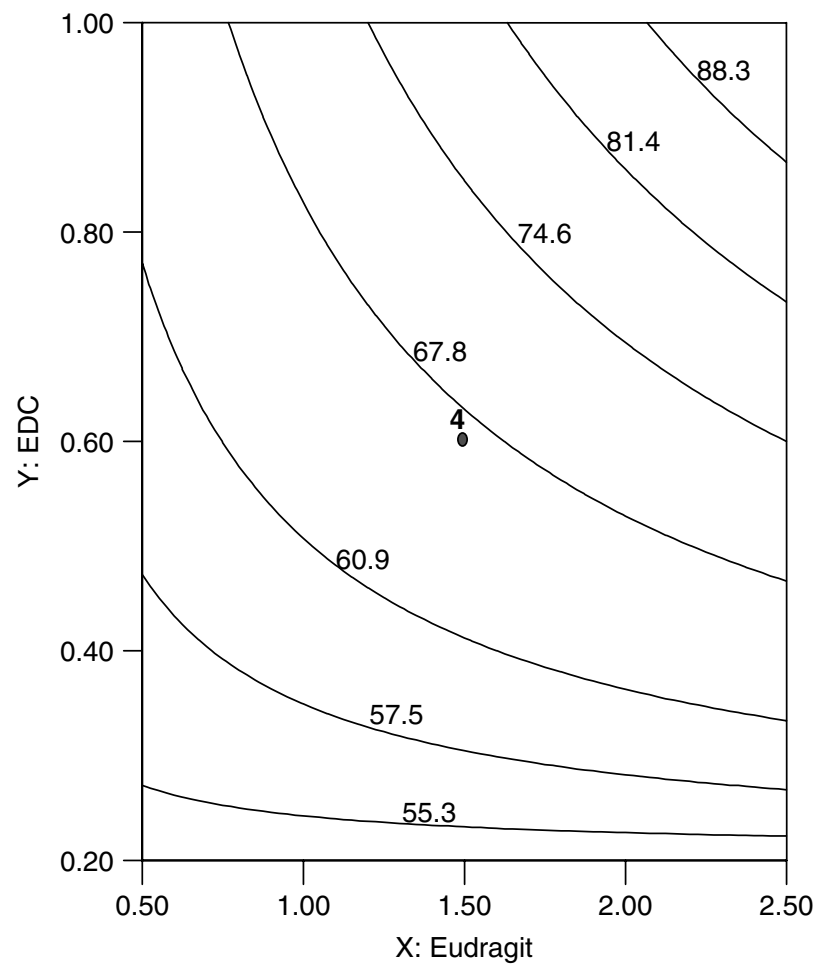

Figure 3. Contour plot showing the effect of Eudragit and carbodiimide concentration on the operational stability of the conjugate at $60^{\circ} \mathrm{C}$. The other factors were kept at the central level.

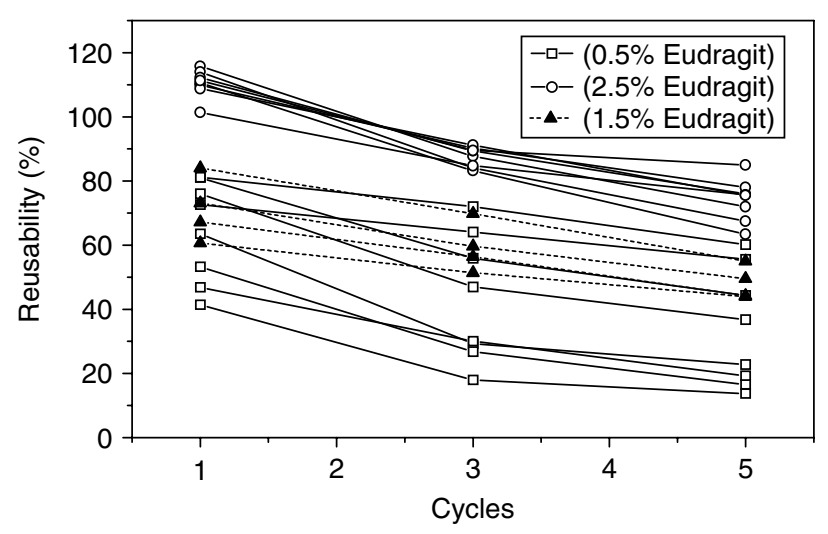

Figure 4. Effect of Eudragit concentration on the remaining activity (in \%) of the conjugate after several cycles of precipitation/dissolution (initial activity was taken as 100\%).

of precipitation/dissolution, was evaluated. Figure 4 shows that the reusability was higher when using the higher concentration of Eudragit in the immobilisation procedure. When using the lower concentration of Eudragit, the reutilisation factor after five repeated cycles of reutilisation varied greatly from $60 \%$ (assay 11) to $14 \%$ (assay 1). Therefore, at the lower level of Eudragit concentration a strong interaction effect between Eudragit and carbodiimide exists, the higher values for $R_{5}$ being attained when carbodiimide is at its maximum level. This variation was not observed when $2.5 \%$ of Eudragit was used in the immobilisation procedure. These last assays were then considered to be covalently crosslinked. It is known that noncovalently bound enzyme is easily lost in repeated 
reaction cycles and Arasaratnam et $a l^{8}$ found that when trypsin was immobilised to Eudragit S-100 in the absence of EDC, only $2 \%$ of the activity was retained after the third cycle.

The serine alkaline protease Protex Multiplus L has a $\mathrm{p} I$ around 9 and coupling to Eudragit S-100 was performed at $\mathrm{pH}$ 7.6. At this $\mathrm{pH}$ the protein is positively charged and the polymer has an opposite charge. It is then likely that hydrophobic interactions do not play a major role in Protex adsorption to Eudragit, favouring the covalent crosslinking. ${ }^{5}$ Also, the immobilisation procedure was performed in the presence of high salt concentrations $\left(0.14 \mathrm{~mol} \mathrm{~L}^{-1}\right.$ $\mathrm{NaCl})$ to cut down adsorption due to electrostatic interactions. ${ }^{7}$

The Student's $t$ test confirms the interaction effect between $A$ and $B$ (Table 3 ). The reusability response presents therefore $A, B$ and the interaction among them as significant factors at $99.5 \%$ confidence level. The model attained for $\mathrm{R}_{5}$, in actual terms is:

$$
\begin{aligned}
\mathrm{R}_{5}(\%)= & -6.14+32.85 A \\
& +49.45 B-21.02 A B
\end{aligned}
$$

The analysis of variance (ANOVA, Table 6) demonstrates that the model is highly significant $(P<0.0001)$ and the $R^{2}$ value, being the measure of the goodness of the fit, indicates that $92 \%$ of the

Table 6. Analysis of variance (ANOVA) to the representative model of reusability, in the range studied

\begin{tabular}{lrrrrr}
\hline Source & \multicolumn{1}{c}{ SS } & d.f. & \multicolumn{1}{c}{ MS } & F-value & $P$ \\
\hline Model & 8509.85 & 3 & 2836.62 & 56.03 & $<0.0001$ \\
Curvature & 103.74 & 1 & 103.74 & 2.05 & 0.1728 \\
Residual & 759.36 & 15 & 50.62 & & \\
$\quad$ Lack of Fit & 677.52 & 12 & 56.46 & 2.07 & 0.2999 \\
$\quad$ Pure error & 81.84 & 3 & 27.28 & & \\
Total & 9372.95 & 19 & & & \\
\hline
\end{tabular}

$R^{2}=0.92 ; \mathrm{CV}=13.49 \%$.

$\mathrm{SS}=$ sum of squares; d.f. $=$ degrees of freedom; $\mathrm{MS}=$ mean square.

Table 7. Coupling of Protex Multiplus $L$ to Eudragit $S-100$, after activation by carbodiimide ${ }^{\mathrm{a}}$

\begin{tabular}{lcrrrr}
\hline \multicolumn{5}{c}{ Specific } \\
Sample & $\begin{array}{c}\text { Protein } \\
\left(\mathrm{mg}^{-1}\right.\end{array}$ & $\begin{array}{c}\text { Activity } \\
(\mathrm{U} \\
\left.\mathrm{mL}^{-1}\right)\end{array}$ & $\begin{array}{c}\text { activity } \\
\left(\mathrm{mg}^{-1}\right)\end{array}$ & $\begin{array}{c}\eta_{\text {protein }}{ }^{\mathrm{b}} \\
(\%)\end{array}$ & $\begin{array}{c}\eta_{\text {activity }^{\mathrm{b}}} \\
(\%)\end{array}$ \\
\hline $\begin{array}{l}\text { Native enzyme } \\
\text { Eudragit-Protex } \\
\text { conjugate }\end{array}$ & 0.77 & 10.35 & 13.44 & 100 & 100 \\
& $0.56^{\mathrm{C}}$ & 4.70 & 8.39 & 73 & 45 \\
\hline
\end{tabular}

${ }^{a}$ Each experiment was done in duplicate. The difference in the individual readings was less than $5 \%$.

${ }^{\mathrm{b}} \eta_{\text {protein }}$ is the protein coupling yield and $\eta_{\text {activity }}$ is the activity yield of Eudragit-Protex conjugate.

${ }^{c}$ Protein measured directly on the conjugate after redissolving using a solution of Eudragit S-100 that followed the same protocol without adding protease as a blank.

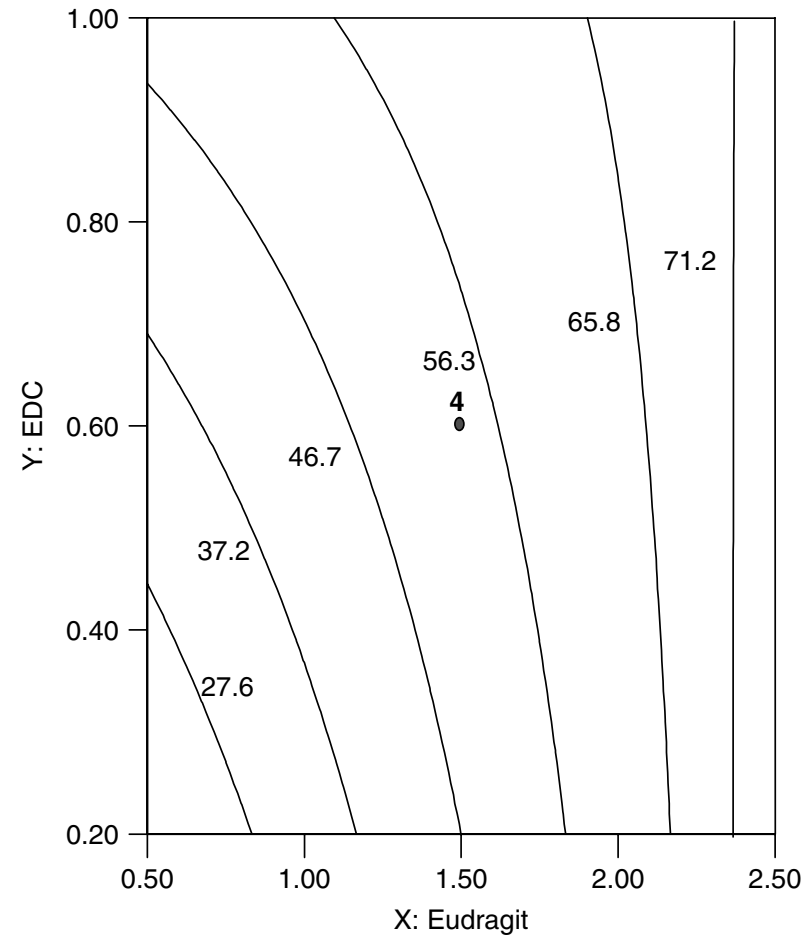

Figure 5. Contour plot showing the effect of Eudragit and carbodiimide concentration on the reusability of the conjugate. The other factors were kept at the central level.

total variation is explained by the model. It presents no curvature and no lack of fit as significant factors.

The contour plot attained for reusability (Fig 5) confirms the existence of an interaction effect at the lower levels of $A$ and $B$, while at the upper level of Eudragit, the concentration of carbodiimide is not affecting this response.

Since it was intended to optimise the immobilisation procedure in order to maximise all the analysed responses, the graphical optimisation of the statistical program 'Design-expert' was performed. The method basically consists of overlaying the curves of the models according to the criteria imposed. ${ }^{20}$ Based on the three models obtained, a graphical optimisation was conducted using a statistical program (Design-expert), defining the optimal working conditions to attain high conjugate activity, operational stability at $60^{\circ} \mathrm{C}$ and reusability. The criteria imposed on the enzyme conjugates were: (a) the activity should be no less than $3 \mathrm{U} \mathrm{mL}^{-1}$, (b) the operational stability at $60^{\circ} \mathrm{C}$ should be more than $50 \%$ and (c) the reusability after the fifth cycle should be above $65 \%$. The overlay plot attained (Fig 6) shows a non-shaded area where all these criteria are satisfied. The time of coupling and the blocking agent concentration were kept at its lower levels $(C=1 \mathrm{~h}$ and $D=0.05 \% \mathrm{v} / \mathrm{v})$ for economic reasons, since they exerted less statistical influence in the responses tested than the Eudragit or carbodiimide concentrations.

Thus, a point was chosen on the graph, which was assigned as optimum point corresponding to $2.5 \%$ $(\mathrm{w} / \mathrm{v})$ of Eudragit (coded level +1$)$ and $0.2 \%(\mathrm{w} / \mathrm{v})$ of carbodiimide (coded level -1 ). As previously stated, 


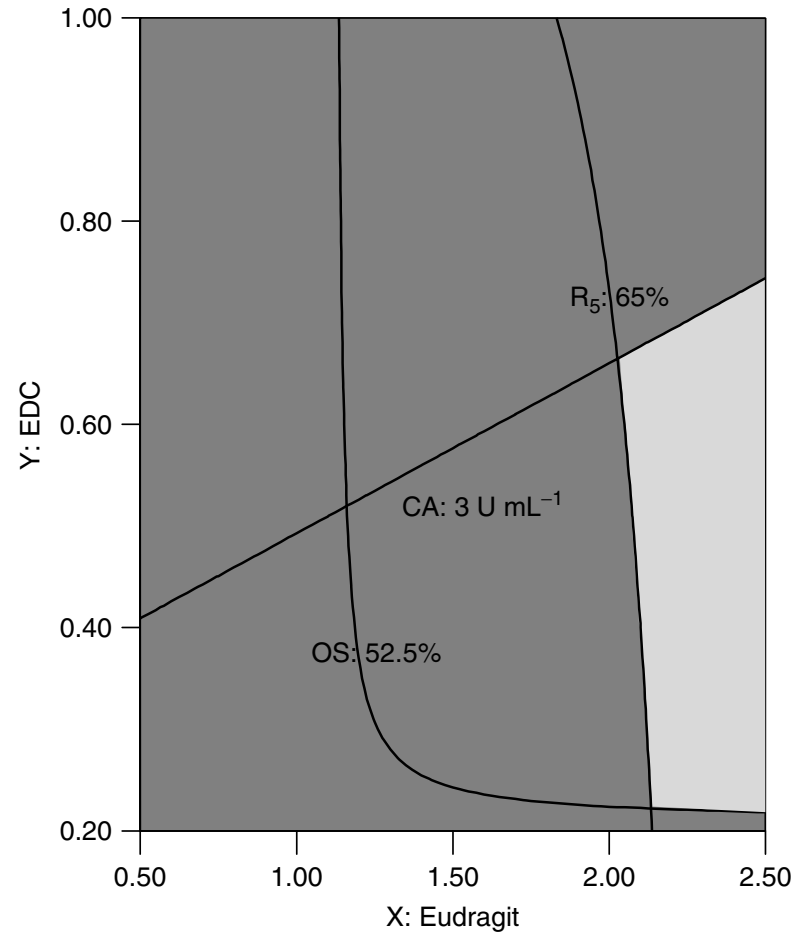

Figure 6. The optimum region by overlay plots of the three responses evaluated (activity, operational stability and reusability) as a function of Eudragit and carbodiimide concentration. The other factors were kept at the lower level.

for economic reasons, the time and blocking agent were set at their lower values. These settings were the same as described by assay 2 of the experimental statistical design. Under these conditions, the models attained predict the following values for the responses, together with the experimental error in the $95 \%$ confidence interval:

Conjugate Activity (CA) : $4.7 \mathrm{U} \mathrm{mL}^{-1}$ [4.50-4.96]

Operational Stability (OS) : 52\%[36.97-67.01]

Reusability $\left(\mathrm{R}_{5}\right)$ : 75\%[67.79-82.96]

The values attained in assay 2 are in good agreement with the predicted values for the analysed responses, validating the mathematical linear models attained.

Regarding the native enzyme, used as control, the following parameters presented in Table 7 were attained for the immobilisation of the commercial alkaline serine protease Protex Multiplus L to Eudragit S-100 in the optimum conditions defined.

The specific activity was lower after immobilisation, confirming the existence of steric hindrance effects. This was expected since multivalent interactions between the enzyme molecule and the polymer after coupling may induce structural rearrangements on the protein molecule. This steric crowding phenomenon has been observed in many earlier studies. ${ }^{8,17,18}$

Interestingly, the specific activity was always higher at the lower levels of carbodiimide used in the coupling procedure (see Fig 7). This result is reinforcing the idea that a clustering effect is occurring: when more

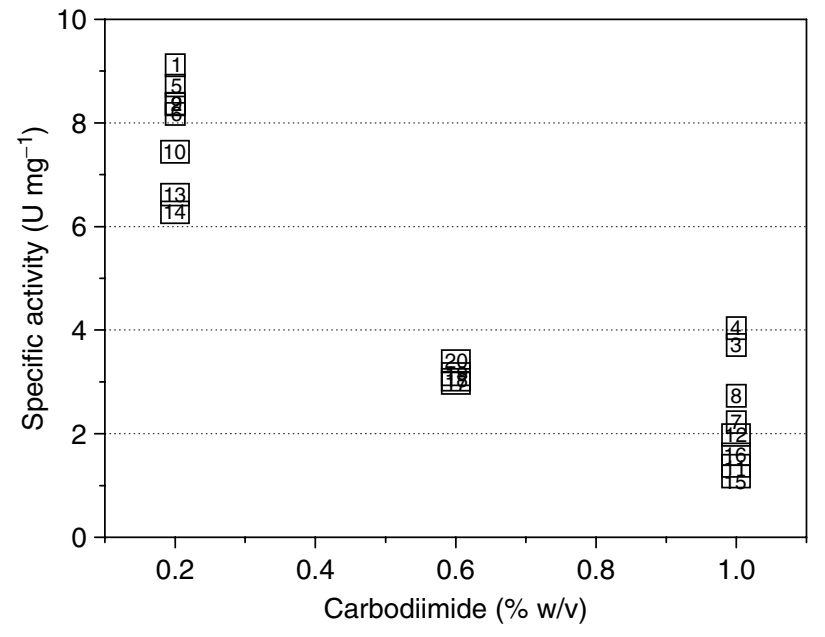

Figure 7. Effect of carbodiimide concentration (\% w/v) on the specific activity of the conjugate. The numbers refer to the number of the assay in the statistical standard order (Table 2).

carbodiimide is added, more intermolecular crosslinks are formed, which may avoid the approach of the macromolecular substrate to the enzyme active site. This phenomenon is likely to be more pronounced with a macromolecular substrate such as casein.

Information about several parameters that influence the immobilisation of proteases into reversibly soluble-insoluble polymers and their interactions can be obtained by the factorial methodology, requiring a limited number of experiments, when compared with classical methods. Using the methodology of experimental factorial design it was possible to determine optimum coupling conditions for a serine protease to Eudragit S-100 and obtain a very stable covalently crosslinked conjugate with high activity and reusability. This optimised conjugate could be attained using lower concentrations of the coupling and blocking agents and less coupling time, giving economic advantages over the previous coupling procedure. More importantly, the non-specific adsorption was eliminated, which represents an improvement in the carbodiimide coupling to Eudragit S-100. This stable biocatalyst can be used for the hydrolysis of macromolecular or insoluble substrates, since it is reversibly soluble-insoluble, eliminating the mass transfer limitations in heterogeneous systems. In addition, the convenient handling of the enzyme preparations, the easy separation of the enzyme from the product and the reuse of the enzyme provides a number of cost advantages, which are often an essential prerequisite for establishing an economically viable enzyme-catalysed process.

\section{ACKNOWLEDGEMENTS}

The authors are grateful for the funding by FCT (Portugal) via PhD fellowship, ref. PRAXIS XXI, SFRH/BD/1292/2000, EU funding for Protex project (G1RD-CT-2002-00695) and also acknowledge the generous gift of Eudragit S-100 from Degussa-Hüls, SA, Barcelona. 


\section{REFERENCES}

1 Heine E and Höcker H, Enzyme treatments for wool and cotton. Rev Prog Coloration 25:57-63 (1995).

2 Fujimura M, Mori T and Tosa T, Preparation and properties of soluble-insoluble immobilized proteases. Biotechnology and Bioengineering 29:747-752 (1987)

3 Taniguchi M, Kobayashi $M$ and Fujii M, Properties of a reversible soluble-insoluble cellulose and its application to repeated hydrolysis of crystalline cellulose. Biotechnology and Bioengineering 34:1092-1097 (1989).

4 Silva CJSM, Sousa F, Gübitz G and Cavaco-Paulo A, Chemical modifications on proteins using glutaraldehyde. Food Technol Biotechnol 42:51-56 (2004).

5 Rodrigues AR, Cabral JMS and Taipa MA, Immobilization of Chromobacterium viscosum lipase on Eudragit S-100: coupling, characterization and kinetic application in organic and biphasic media. Enzyme and Microbial Technology 31:133-141 (2002).

6 Sardar M, Agarwal R, Kumar A and Gupta MN, Noncovalent immobilization of enzymes on an enteric polymer Eudragit S-100. Enzyme and Microbial Technology 20:361-367 (1997).

7 Tyagi R, Roy I, Agarwal R and Gupta MN, Carbodiimide coupling of enzymes to the reversibly soluble insoluble polymer Eudragit S-100. Biotechnol Appl Biochem 28:201-206 (1998).

8 Arasaratnam V, Galaev IY and Mattiasson B, Reversibly soluble biocatalyst: optimization of trypsin coupling to Eudragit S100 and biocatalyst activity in soluble and precipitated forms. Enzyme and Microbial Technology 27:254-263 (2000).

9 Silva CJSM and Roberto IC, Statistical screening method for selection of important variables on xylitol biosynthesis from rice straw hydrolysate by Candida guilliermondii FTI 20037. Biotechnology Techniques 13:743-747 (1999).

10 Serralha FN, Lopes JM, Lemos F, Ramôa Ribeiro F, Prazeres DMF, Aires-Barros MR and Cabral JMS, Application of factorial design to the study of an alcoholysis transformation promoted by cutinase immobilized on $\mathrm{NaY}$ zeolite and Accurel PA6. Fournal of Molecular Catalysis B: Enzymatic 27:19-27 (2004).

11 Moyo S, Gashe BA, Collison EK and Mpuchane S, Optimising growth conditions for the pectinolytic activity of Kluyveromyces wickerhamii by using response surface methodology. International fournal of Food Microbiology 85:87-100 (2003).

12 Cortez EV, Pessoa Jr A, Felipe MGA, Roberto IC and Vitolo M, Optimized extraction by cetyl trimethyl ammonium bromide reversed micelles of xylose reductase and xylitol dehydrogenase from Candida guilliermondii homogenate. Fournal of Chromatography B 807:47-54 (2004).

13 Mayerhoff ZDVL, Roberto IC and Franco TT, Purification of xylose reductase from Candida mogii in aqueous two-phase systems. Biochemical Engineering fournal 18:217-223 (2004).

14 Box GEP, Hunter WG and Hunter SJ, Statistics for Experimenters. Wiley, New York (1978).

15 Lowry OH, Rosebrough NJ, Farr AL and Randall RJ, Quantitation of protein using Folin Ciocalteau reagent. F Biol Chem 193:265-275 (1951).

16 Laemmli UK, Cleavage of structural proteins during assembly of head of bacteriofage-T4. Nature 227:680-685 (1970).

17 Dourado F, Bastos M, Mota M and Gama FM, Studies on the properties of Celluclast/Eudragit L-100 conjugate. Fournal of Biotechnology 99:121-131 (2002).

18 Sardar M, Roy I and Gupta MN, Simultaneous purification and immobilization of Aspergillus niger xylanase on the reversibly soluble polymer Eudragit ${ }^{\mathrm{TM}}$ L-100. Enzyme and Microbial Technology 27:672-679 (2000).

19 Sharma S, Kaur P, Jain A, Rajeswari MR and Gupta MN, A smart bioconjugate of chymotrypsin. Biomacromolecules 4:330-336 (2003).

20 Silva CJSM and Roberto IC, Optimization of xylitol production by Candida guilliermondii FTI 20037 using response surface methodology. Process Biochemistry 36:1119-1124 (2001). 